\title{
Research on the Integration of Innovative Entrepreneurship Education and Professional Teaching in Art
}

\author{
Mei Xu \\ Liaoning Institute of Science and Engineering, Jinzhou, Liaoning, 121000
}

Keywords: Entrepreneurship Education, Professional Teaching, Art.

\begin{abstract}
Art design professional and social close, very suitable for students to start. Art design students need to improve the quality of entrepreneurship, entrepreneurship education and professional teaching integration, the creation of art design post application courses, and actively looking for entrepreneurship education and professional courses of the combination of the art design process into the entrepreneurial education, Cultivate the spirit of innovation as the core of entrepreneurship teaching and practice platform for independent entrepreneurship and lay a solid foundation.
\end{abstract}

\section{Introduction}

Colleges innovation and entrepreneurship education is based on the professional characteristics of the model, to cultivate a sense of innovation, innovation, innovation, innovative thinking and other advanced application-oriented education. In recent years, innovation and entrepreneurship education has become one of the steps to deepen the reform of education and teaching and cultivate students' innovative spirit and entrepreneurial ability. However, in the process of innovation and entrepreneurship education in Colleges, there are still the following problems: innovation and entrepreneurship education is too single. Part of the vocational college innovation and entrepreneurship project is only stay in the commercial trading activities and other fields, not with the students professional expertise to carry out innovative entrepreneurship education, not to inspire students for the purpose of innovation and wisdom, innovation and entrepreneurship is too narrow. Innovative entrepreneurship education teachers are not strong. Colleges innovation and entrepreneurship education teachers mainly by professional teachers and employment work as a teacher, the lack of mentor from the enterprise. And professional teachers and employment work instructors on the current mode of operation of enterprises do not know much and can not stimulate students desire and potential for innovation and entrepreneurship. Innovative educational materials are not perfect. At present, there are few kinds of teaching materials of innovation and entrepreneurship education in Colleges, and the content of teaching materials is only at the theoretical level. There is a lack of imitable entrepreneurial success stories in the teaching materials, and the analysis of the failure cases is only a general discussion, so the lack of innovative ideas, innovative practice and entrepreneurial ability as the main content of the teaching materials. Innovation and entrepreneurship education not only focus on cultivating students 'sense of entrepreneurship, innovative spirit, but also focus on improving the overall quality of students' innovation and entrepreneurship, especially the ability to innovate and practice. Through innovation and entrepreneurship education to stimulate students to innovation and entrepreneurship initiative and creativity, not only to create more jobs, reduce social employment pressure, but also for the country to create more wealth and promote the harmonious development of society. Colleges to carry out innovative entrepreneurship education, but also reflects the connotation of quality education, not only to develop students a sound personality, but also to develop students' independence, initiative and creativity. 


\section{The Present Situation of Practical Teaching in Art Design}

With the development of social productive forces, especially the new design ideas, new technologies and new technologies, the market has put forward higher requirements for the professional training mode of art and design in Colleges. The traditional practice teaching mode can not meet the innovation Type of personnel training needs. The reason, mainly the following:

Practical teaching teachers are weak. Most of the higher vocational art design professional practice teaching work mainly by young professional teachers. Young teachers are mostly college graduates of art, solid theoretical knowledge, but the lack of business experience, less practical experience in the industry, master the information update is slow. Therefore, the actual operation ability of teachers is not high, which leads to the professional design of art and design courses, the effect of practical training is not ideal, but also affect the quality of art professional practice and the improvement of students' practical ability.

Practical teaching system is not complete. At present, the professional training courses of professional design of art and design in Colleges, graduation design, internship practice and so on are not isolated from each other, and there is no complete system. Art practice professional practice teaching system is not complete and not system led to the practice of students can only be superficial, repetitive, training students are only focused on a job and job skills, professional comprehensive ability is difficult to improve. Practical teaching content is not perfect. Most of the professional design of art and design in Colleges in the curriculum design, teaching design and teaching content selected by the school to complete the professional teachers, there is no social industry, business personnel to participate. In the arrangement of teaching content, the general theory of light practice, which led to the development of art and design professionals training programs and practical teaching content and industry, business needs there is a gap, lack of targeted teaching practice, teaching and social needs out of touch.

\section{Integration of Entrepreneurship Education and Professional Teaching in Art Design}

In order to adapt to the employment and entrepreneurship of art and design students, the teaching of art and design courses should be practical and innovative. When teaching professional courses, professional teachers should analyze and explain the positions of art and design professionals in the post on the art design management business aspects of the art design theory knowledge and to explore and develop potential professional applications for art design applications. Most of the students in the arts and design profession are engaged in advertising copy planning, network design, interior decoration, exhibition display, jewelry design and graphic design and so on. The industry is involved in the media, decoration, and so on. Students in these positions on the main content of the work, and in order to better work, the specific need to master the art design related to what knowledge, how to accumulate and innovate in these positions, and further independent development, are our art design Workplace practice application courses need to be involved in the content. At the same time, the art design profession has a strong social application, and its ultimate service for business applications, we have to continue to explore and develop potential art design jobs based on the changing economic situation and provide new students for art and design students Employment and entrepreneurial point, as the main content of the application of art design work, which can make the art design professional curriculum content more pragmatic, easy to better develop students' sense of employment and entrepreneurial awareness.

Art design is a very professional application, the designer needs to work with customers, construction workers, design teams and other groups in order to achieve the final completion of the project. Therefore, students who want to start a business need to master the management and operation of the entire professional design company. Therefore, as a professional design company with the management and operation of the close combination of professional, art design teaching courses set up with the entire design process is closely linked to the operation process, and phased.

First of all, professional courses taught to improve the level of professional skills based on the students, the entrepreneurial needs of the quality and skills with professional teaching integration. 
In the teaching process, through the establishment of a variety of teaching links, simulation design project operation process. For example, in the advertising planning and design courses involved in the creation of advertising creative books, advertising products, market research, market research, advertising planning and other aspects of the teaching tasks, you can use the task set to simulate real teaching so that students in the Practice in a phased manner to complete the task, to experience the completion of an advertising planning and design projects in all aspects of these links and the contents of the course of teaching closely integrated to improve the quality of students' entrepreneurship.

Second, the art and design professional has a strong social practice, you can set up by the arts and design professional entrepreneurial education project operation courses to improve students' comprehensive use of professional knowledge and skills of entrepreneurial quality, through the completion of the course of study, so that students close to the real market Application in the environment. Professional courses can be set up with professional design companies to cooperate, cooperation projects can be the company is running the project, the content can include market research, communication with customers, writing planning, design creation, market evaluation and so on. Arrangements for the operation of the Entrepreneurship Program will be carried out in accordance with the actual process of the project operation, in close connection with the professional courses that students have already learned so as to enable students to develop their own initiative and experience the complete business process. At the same time, students can take the initiative to communicate with the initiators and employees of the company while completing the design company project, and get more and more entrepreneurial experience.

Art design industry in the early stages of entrepreneurship to focus on the creation of the design studio, do not need more capital investment, business risk is not high, students can be shorter during the operation of the art design skills level, through the completion of the project operation, Art design products to meet the individual needs of customers. This size of the design studio is to undertake the design project, in the process of undertaking the project needs to be applied to the team's organization, how to communicate with customers, design creative practice, project management and application and customer maintenance and some other knowledge And skills. Therefore, we should be in the daily teaching process, the entire art design project into the teaching process, professional teachers to find professional courses and entrepreneurial processes fit the point, the teaching links to match the entrepreneurial process, to guide students to experience The real entrepreneurial process, to cultivate students 'entrepreneurial ability and improve the students' comprehensive entrepreneurial quality.

First of all, to the art design project process into the entrepreneurial education, it is necessary to the employment of students and business design talent needs to do meticulous research, in particular, through research to master the students should have the core employment and entrepreneurial ability, According to the results of the survey, the introduction of teaching projects. For example, the introduction of corporate advertising copy project. The introduction of this project is because most of the advertising students after graduation in newspapers, magazines, Internet companies, media companies engaged in advertising planning work, but also suitable for students to start business. In the introduction of the project to the teaching link, we have to consider the communication between professional courses and coordination issues, as well as the various aspects of entrepreneurship education system, students in the completion of professional courses in the business process, the rational use of the previous study related information. For example, advertising students in the completion of corporate advertising copy project planning and on the one hand teaching arrangements to meet the design talent to set the job standards, on the other hand also requires students to learn the general planning process of advertising planning, with the completion of planning Skill level of the project. Secondly, in the teaching process, we will introduce the project and the teaching part of the interlocking, teaching participants can be on the teaching content and teaching process to make appropriate adjustments. In the process of art design project into the entrepreneurial education, to learn from the enterprise management model to carry out the management of teaching, to clear the division of the entire art design project, each link must clear 
the work tasks, job responsibilities and work standards. At the same time in every aspect should pay attention to supervision, pay attention to communication with customers and design in practice. In the teaching process, especially in the teaching evaluation link, we should pay attention to meet the individual requirements of the development of students, students show unique design ideas and design work to actively encourage and personal guidance.

China is vigorously creating an innovative country, the art and design industry is responsible for cultural and artistic innovation and economic development of the major mission, its level of innovation will become the future of national cultural innovation core competitiveness. Art design students to use their own design expertise and professional skills, by playing their own innovative spirit, to complete an art design work, which contains students to master the design expertise, but also contains the students creativity Level play. Therefore, we have to build students to cultivate students' innovative spirit as the mainstay of entrepreneurship education teaching and practice platform, training students to design skills and innovative, keep creative creative spirit, so as to cultivate students creativity and entrepreneurial awareness Intrinsic core driving force.

\section{Conclusion}

Practical teaching is an indispensable link in the innovation and entrepreneurship education system, and it is also one of the important ways to cultivate college students' innovation and entrepreneurship and innovation and entrepreneurship ability. It is an important role to improve the practice teaching effect, improve the students' practical ability, entrepreneurial ability and employability. It is in line with the training goal of art and design specialty.

\section{References}

[1] Xu Qing. Anime professional construction and development of ideas I see [J]. Brand, 2015 (01)

[2] Ye Yewen. Animation industry development perspective of animation teaching reform strategy [J]. Yalu River, 2015 (11)

[3] Ji Hui. Focus on the status quo in the animation professional talent training [J]. Talent Road. $2013(10)$

[4] Zong Ling. Animation professional project teaching method reform research [J]. Tomorrow fashion, 2017 (09)

[5] Xu Fengju. Animation professional practice teaching method reform [J]. Art Technology, 2016 (12)

[6] Yuan Xuemei, Luo Changgen. Higher vocational animation professional hand-painted teaching analysis [J]. Science and Technology Economic Guide, 2017 (09) 